Prace Literackie LVIII

Wrocław 2018

https://doi.org/10.19195/0079-4767.58.20

TOMASZ ŚLĘCZKA

ORCID: 0000-0002-2711-4732

Uniwersytet Wrocławski

\title{
Diariusz i listy. Kilka uwag o charakterze pism Kazimierza Sarneckiego
}

Badacze dziejów schyłku panowania Jana III Sobieskiego chętnie sięgają po sporząazzane przez Kazimierza Sarneckiego dla podkanclerzego litewskiego Karola Stanisława Radziwiłła relacje z dworu polskiego monarchy, uznając je za wartościowe i wiarygodne źródło informacji ${ }^{1}$.

Sarnecki pełnił na królewskim dworze funkcję oficjalnego rezydenta litewskiego magnata i z racji zarówno więzów krwi, łączących Sobieskiego z Radziwiłłem, jak i przynależności tego drugiego do stronnictwa regalistycznego, cieszył się tam pewnymi względami, które ułatwiały mu wypełnianie obowiązków ${ }^{2}$. Wywiązywał się z nich chyba dobrze, bo poza nielicznymi odgłosami niezadowolenia mocodawcy, których echo znajdujemy na kartach relacji, utrzymał swe stanowisko co najmniej do końca panowania Sobieskiego (a być może i dłużej, o czym jednak nie sposób wiążąco stwierdzać ze względu na całkowite milczenie źródeł).

${ }^{1}$ K. Sarnecki, Pamiętniki z czasów Jana Sobieskiego. Diariusz i relacje z lat 1691-1696, oprac. J. Woliński, Wrocław 1958 (wszystkie cytaty pochodzą z tego wydania, oznaczam je bezpośrednio w tekście głównym podaniem numeru strony). O Kazimierzu Sarneckim zob. Sarnecki Kazimierz, [w:] Polski słownik biograficzny, Warszawa-Kraków 1987, t. 35, s. 208-209. Zwięzła biografia Karola Stanisława Radziwiłła zob. A. Rachuba, Radziwitł Karol Stanisław, [w:] Polski słownik biograficzny, Warszawa 1987, t. 30. Opinie o wartości dzieła zob. między innymi Z. Wójcik, Jan Sobieski 1629-1696, Warszawa 1983, s. 482 („,nieoceniony kronikarz”), ostatnio A. Skrzypietz, Jakub Sobieski, Poznań 2018, s. 394 („,bardzo cenne [...] dzieło”). Podobnych określeń można oczywiście znaleźć znacznie więcej.

${ }^{2}$ Był, najogólniej mówiąc, „okiem i uchem” swego patrona, czyli i przedstawicielem dyplomatycznym, i szpiegiem, i wykonawcą jego rozlicznych poleceń. Zob. więcej W. Czapliński, J. Długosz, Życie codzienne magnaterii polskiej w XVII wieku, Warszawa 1976, s. 181-185. 
Interesującym zagadnieniem, nad którym warto by się pochylić badaczowi literatury, jest kwestia klasyfikacji gatunkowej tego dzieła.

Gdybyśmy oddali głos samemu autorowi, dowiedzielibyśmy się, iż sporządzał dla księcia podkanclerzego dwa odrębne typy tekstów: diariusz oraz listowne relacje (napisze na przykład „cały diariusz tego tygodnia i listy gotowe wszystkie mając" [227]) $)^{3}$. Dzisiejszym badaczom ta nieskomplikowana dychotomia wydaje się jednak nie wystarczać, szukają więc terminu, który z maksymalną precyzją objąłby całość zachowanego materiału. Problem jednak w tym, że - co postaram się w niniejszym szkicu udowodnić - terminu takiego ukuć się nie da, propozycje zaś, które pojawiły się w trakcie badania odmian gatunkowych polskiego pamiętnikarstwa, i tak nie są wystarczająco dokładne, zatem pozostanie przy terminologii przyjętej przez samego autora wydaje się rozwiązaniem najlepiej określającym charakter jego dzieła.

\section{Metoda pracy Sarneckiego}

Podstawowym zadaniem stolnika witebskiego było pisanie regularnego diariusza, w którym zawierał wszystko to, czego danego dnia się dowiedział, oraz informował o podejmowanych działaniach. O sobie wspomina wyłącznie wtedy, gdy jego posunięcia związane są z szeroko pojętym interesem patrona (w jego imieniu przekazuje listy i informacje, odpowiada na pytania króla i królowej, załatwia różne zlecenia), na ogół jednak kryje się za swym tekstem i nie prezentuje własnych opinii lub ocen.

Nazywając tę część pisarskich dokonań Sarneckiego diariuszem, postępujemy oczywiście za autorem - on sam wielokrotnie posługiwał się tą nazwą i w taki właśnie sposób określał swe skrupulatnie sporządzane zapiski (na przykład „Kontynuacyą diariusza mego, na którym dniu on przestałem donosić w.ks.m. dobrodziejowi posyłam [...]" [228]). Milczały o nim ówczesne podręczniki, gdyż ten czysto użytkowy gatunek niewiele miał wspólnego z literackością ${ }^{4}$. Diariusze

${ }^{3}$ Dołączał do nich różne pisma, pochodzące od osób trzecich, uzupełniając w ten sposób przekazywane wiadomości o wieści z miejsc, w których nie był; na przykład w kwestii zagrożenia tatarskiego chętnie wyręczał się relacjami lwowskiego rajcy Dominika Wilczka — zob. A. Sajkowski, W stronę Wiednia. Dole i niedole wojenne w świetle listów i pamiętników, Poznań 1984, s. 313-325. O powszechnie stosowanej wówczas praktyce włączania w obręb diariuszy tekstów obcych zob. między innymi P. Borek, Ukraina w staropolskich diariuszach i pamiętnikach, Kraków 2001, s. 29-82. Warto pamiętać, że analizowana przez krakowskiego badacza sylwiczność pojawia się u Sarneckiego w dwu postaciach — pierwszą jest dołączanie tekstów obcych do całości wysyłanej poczty, drugą zaś inkorporowanie tekstów obcych w obręb diariusza. Są to jednak dwie odmiany tego samego zjawiska. Ponieważ pisma te nie mają znaczenia dla gatunkowej klasyfikacji dzieła Sarneckiego, pomijam je zatem w dalszych partiach tego szkicu.

${ }^{4}$ Nie zmienia tego nawet fakt, że „w XVII wieku pamiętnikarstwo jest prawie wyłącznym terenem kształtowania się stylów i technik prozy narracyjnej” (H. Dziechcińska, Pamiętnik, [w:] Stownik literatury staropolskiej, red. T. Michałowska, Wrocław 1998, s. 613). 
sporządzano z najrozmaitszych okazji, a ,podstawową zasadą strukturalną [...] był zapis dzienny, z konieczności dzielący relacje o większym zespole zdarzeń na poszczególne ogniwa, zamknięte ramą jednego dnia. Taka mechaniczna kompozycja diariusza z góry wyznaczała wyłącznie chronologiczny układ materiału"5.

Warto zauważyć, że w obrębie zachowanego materiału odnajdujemy trzy odmiany diariusza: pierwszym jest wojenny, pisany podczas kampanii mołdawskiej 1691 roku, drugim „zwyczajny”, regularny diariusz prowadzony podczas pobytu na dworze królewskim aż do momentu zgonu króla, trzecim diariusz sejmu 1695 roku. Oba te "nadzwyczajne” diariusze, relacjonujące wydarzenia wojenne oraz spory parlamentarne, różnią się strukturalnie od „zwyczajnego" — o czym niżej.

Każda „zwyczajna” diariuszowa notatka powiela niemal identyczny schemat: stan zdrowia króla, sprawy dotyczące księcia podkanclerzego (w szczególności poczynania „księżnej dobrodziejki”, czyli siostry króla a matki Karola Stanisława Katarzyny z Sobieskich Radziwiłłowej), wreszcie rzeczy inne ${ }^{6}$. Odstępstwa od tej kolejności nie są częste (w zachowanym materiale będą to 63 przypadki na kilkaset notatek); nawet jednak gdy pierwsze zdanie dotyczy innej tematyki (najczęściej będzie to pogoda, królowa, sprawy publiczne), to w drugim, najdalej trzecim pojawi się wzmianka o stanie zdrowia Sobieskiego (bo ta kwestia interesowała Karola Stanisława najbardziej).

Inaczej nieco mają się sprawy w wypadku diariusza kampanii mołdawskiej oraz sejmowego. Ani jeden, ani drugi nie poświęca większej uwagi stanowi zdrowia monarchy, koncentrują się zaś na samych zdarzeniach — posunięciach wojsk, walkach i wojennych niedostatkach w przypadku pierwszego oraz sporach wśród koronnych i litewskich dygnitarzy w drugim; jednak po zakończeniu relacjonowania kampanii mołdawskiej oraz sejmu 1695 roku powraca do zwyczajnej formy regularnego diariusza.

Sarnecki prowadził nie tylko diariusz. Mniej więcej co tydzień ${ }^{7}$ sporządzał obszerną relację, ujętą w ramy listu, i do tej relacji dołączał, tworząc jeden pakiet, diariusz pisany w czasie między wysłaniem poprzedniego listu a napisaniem kolejnego. W liście znacznie szerzej niż na kartach diariusza informował o swych czynnościach i posunięciach, będących realizacją pańskiej woli. Realizacją — jak to niejednokrotnie sam akcentuje — wyjątkowo staranną i rzetelną. W listach tych

${ }^{5}$ H. Dziechcińska, Diariusz, [w:] Słownik literatury staropolskiej, red. T. Michałowska, Wroclaw 1998, s. 164. Tam też zwięzły przegląd podstawowej literatury przedmiotu.

${ }^{6}$ Spektrum zainteresowań Karola Stanisława Radziwiłła było bardzo szerokie (choć jego zdolności intelektualne nie znalazły uznania ani u współczesnych, ani późniejszych badaczy dziejów potężnego rodu litewskich magnatów), więc relacje stolnika witebskiego pełne są najrozmaitszego materiału — od spraw publicznych poczynając, na pozamałżeńskich stosunkach żony kucharza kończąc; więcej zob. T. Ślęczka, Świat zainteresowań siedemnastowiecznego magnata. Relacje Kazimierza Sarneckiego o dworze Jana III Sobieskiego, [w:] Epistolografia w dawnej Rzeczypospolitej, t. 7, red. P. Borek, M. Olma, Kraków 2017, s. 225-240.

${ }^{7}$ Choć zdarzało się i częściej, gdy sprawy nagliły — jak po pojawieniu się kwestii kurateli nad dobrami neuburskimi. 
uzupełniał podawane w diariuszu informacje, prostował też błędy, które wynikały z właściwej diariuszowi metody zapisywania zdarzeń wedle ich porządku, bez chronologicznie odleglejszej refleksji. Relacje te nadawały zatem całości pewnej — co prawda niewielkiej — głębi.

O ile co do diariusza nie dało się odwołać do istniejącego wzorca normatywnego — bo takiego nie było — inaczej rzecz cała wyglądała w kwestii listu ${ }^{8}$. Mimo iż znajdował się on w pewnym sensie na obrzeżach literatury i piśmiennictwa (a pozycja ta wynika z jego na poły użytkowego charakteru' ${ }^{9}$ ), to doczekał się wcale solidnej obudowy teoretycznej. Sarnecki - choć nie umiemy stwierdzić, jakimi drogami podążała jego edukacja — mógł oczywiście odwołać się do stosunkowo wówczas nowej pracy Samuela Obodzińskiego ${ }^{10}$, jednak w późniejszym czasie listowniki zaczęły powstawać praktycznie masowo ${ }^{11}$, więc trudno przesądzić o konkretnym źródle jego epistolograficznej sprawności. Równie dobrze mógł ją zresztą nabyć w praktyce i uczyć się nie z podręcznika, lecz w trakcie kancelaryjnej pracy.

Za wyborem wspomnianej dwudzielnej konstrukcji stały — jak sądzę przede wszystkim względy praktyczne ${ }^{12}$ — poczta wychodziła wówczas nieregularnie, drogi były niepewne, a ryzyko zagubienia lub kradzieży przesyłki znaczne, korzystniej więc było wysłać solidniejszą przesyłkę co jakiś czas, niż szukać okazji każdego dnia. Może też — choć nie ma na to dowodów — powodem była oszczędność - przyjęta metoda była również tańsza, gdyż wysłany z listem sługa generował koszty, których można było uniknąć, ekspediując pocztę zwyczajną drogą. Siedemnastowieczni magnaci nie cierpieli na nadmiar gotówki, częściej borykali się z jej brakiem niż nadmiarem, zatem i tego rodzaju oszczędność mogła wpłynąć (co prawda w dość okrężny sposób) na decyzje pisarskie Sarneckiego.

Stolnik witebski, mimo iż finalnie wszystkie zapisane w ciągu tygodnia karty trafiały do jednego pakietu, sam postrzegał odrębność części diariuszowej od epistolograficznej, czego najwyrazistszym przejawem są widoczne różnice konstrukcyjne między nimi.

${ }^{8}$ Zob. T. Lancholc, List, [w:] Stownik literatury staropolskiej, red. T. Michałowska, Wrocław 1998, s. 456-457. Tu przegląd w miarę nowej literatury przedmiotu. Skorzystać możemy z dawnej — aczkolwiek wciąż aktualnej — pracy Stefanii Skwarczyńskiej (Teoria listu, Lwów 1937), jednak odnośnie do listu staropolskiego lepszym pomysłem będzie odesłanie do ukazującej się w mniej więcej dwuletnich odstępach serii Epistolografia w dawnej Rzeczypospolitej, red. P. Borek, M. Olma.

${ }^{9}$ Stąd bierze się obudowane wielowiekową tradycją rozróżnienie listu literackiego oraz użytkowego (T. Lancholc, op. cit., s. 456).

${ }^{10}$ S. Obodziński, Promptuarium epistolographicum, tj. listopistwa politycznego model, Lwów 1665.

${ }^{11} \mathrm{O}$ staropolskich listownikach zob przede wszystkim prace M. Kurana w kolejnych tomach Epistolografia w dawnej Rzeczypospolitej.

12 Nie wiemy, czy był to wybór Sarneckiego, czy wynikało to z zalecenia jego patrona, ostrożnie można założyć, że stała za tym pańska wola - inaczej Sarnecki mógłby nie czuć się zobowiązany do wylewnego przepraszania za opóźnienia, nie zawsze zresztą zawinione. 
Po pierwsze, zachowywał należne listowi klienta do patrona formuły salutacyjne oraz subskrypcje, których próżno szukać w kolejnych wpisach w diariu$\mathrm{szu}^{13}$. Za każdym razem, kiedy wspomina o swym patronie, czyni to z należytym szacunkiem, jednak w diariuszu zazwyczaj nie są to zwroty bezpośrednio do niego skierowane („Król jm. [...] pytał mię, jeżeli w.ks.m. pewnie się obiecał na sejmik brzeski; odpowiedziałem, że: tak jest, mit. królu [...] i że w.ks.m. pisał directe do króla jm." [56]). Natomiast w listach znajdziemy takich zwrotów znacznie więcej: „Kiedy tę pocztę prima incipientis anni piszę, nie godzi mi się tylko upadszy do majestatu tego Pana, który jest caput omnium dominantium, prosić go, aby w.ks.m. panu i dobrodziejowi memu miłościwemu jako najdłużej dobrego użyczał zdrowia, a i przy pomyślnych sukcesach in multas tantorum annorum revolutiones wszelkimi osobę i dom jego de lumbis ipsius pochodzący ubogacał na zaszczyt upadającej ojczyzny naszej błogosławieństwy" [270].

Po drugie, odmiennie segregował materiał. W listach próżno byłoby szukać wskazanej przy omawianiu diariusza mniej więcej stałej struktury (najpierw król, potem reszta); tutaj selekcją materiału rządzi raczej (o ile można to stwierdzić) hierarchia ważności spraw dla podkanclerzego litewskiego bądź też ewentualnie ich chronologiczne następstwo. W listach jest też miejsce na prostowanie podanych wcześniej informacji (choć czyni tak i w diariuszu, nie czekając na moment, w którym zasiądzie do pisania listu), relacjonowanie stanu zleconych przez patrona czynności itp. Niejeden raz w liście Sarnecki zaznaczy: „nie przydaję do diariusza mego więcej, bo dosyć sufficienter et fideliter, co uszy moje słyszeli, wyraziłem" [285]. Wyraźnie wskazuje to na uzupełniający względem diariusza charakter epistoły.

Po trzecie wreszcie, to w listach wchodzi w rozmaite interakcje $\mathrm{z}$ księciem podkanclerzym: reaguje na jego zalecenia, usprawiedliwia się bądź uniżenie kaja za popełnione błędy. W diariuszu nie natrafimy na takie fragmenty jak w listach: „Tę admonicyją, którą odbieram od w.ks.m. dobrodzieja, na cały żywot w sercu moim chować będę jako od dobrotliwego, wielkiego rozsądku pana, żem zgrzeszył przez niesłuchanie, i napomnienie pańskie dziesiątemu powiem, jako pana trzeba słuchać, bo widzę na sobie, że się to prawdzi: kto pana nie słucha, Boga nie słucha" [238].

\section{Polskie klasyfikacje prozy pamiętnikarskiej}

Dwudzielna struktura pism Sarneckiego nie ułatwia prób klasyfikacji, mimo to były one oczywiście podejmowane, kwestia zaś wpisania dorobku stolnika wi-

13 Zob. T. Ślęczka, Skromny i staranny. Wybrane zagadnienia warsztatu pisarskiego Kazimierza Sarneckiego, rezydenta Karola Stanisława Radziwitła na dworze Jana III Sobieskiego, „Prace Literaturoznawcze" 2017, s. 65-68. 
tebskiego w ramy odmian staropolskiego pamiętnikarstwa nie została póki co zadowalająco rozstrzygnięta.

W tej części pracy przyjrzymy się poszczególnym propozycjom, które przyniosły badania literaturoznawcze. Oczywiście na polu prozy pamiętnikarskiej działają również historycy i socjologowie, jednak ich koncepcje tworzone są z innych punktów widzenia i odpowiadają innym potrzebom. Chętny czytelnik wiele wiadomości znajdzie w studium Jerzego Maternickiego, który omówił istniejące propozycje systematyki polskiego pamiętnikarstwa oraz zaprezentował własne ${ }^{14}$.

Dokładniejsze badanie pism Sarneckiego rozpoczyna się wraz z ich wydaniem przez Janusza Wolińskiego. Wydawca nadał im tytuł Pamiętniki z czasów Jana Sobieskiego i zaopatrzył w bliżej objaśniający sprawę podtytuł Diariusz i relacje z lat 1691-1696. W zwięzłym wstępie wydawca nie zajął się kwestiami genologicznymi, wskazał jedynie na trójdzielny charakter zachowanego materiału, który tworzą wskazane w podtytule diariusz oraz relacje, jak też pisma pochodzące od osób trzecich, dołączane przez Sarneckiego ${ }^{15}$.

Pewne wątpliwości może budzić wybita na pierwszy plan tytułu nazwa ,pamiętniki”. Wydaje się, iż w zamyśle wydawcy miała na celu wskazanie — przez użycie powszechnie kojarzonego z zapisem przeszłości terminu — na ogólnie rozumianą dawność tekstu i jego związek z narracją wspomnieniową, nie zaś określać go gatunkowo (czemu wszak przeczyłby podtytuł, w którym znajdujemy poprawne terminy, charakteryzujące obie części dorobku Sarneckiego) ${ }^{16}$. Nie jest to także - co warto zaznaczyć - pojęcie nadrzędne wobec różnych form pamiętnikarskich $^{17}$, zatem i z tego punktu widzenia wydaje się nie do przyjęcia.

Sama nazwa „pamiętnik” w zbliżonym do naszego rozumieniu pojawiła się dość późno ${ }^{18}$. Oznacza odmienny od diariusza typ tekstu: „narracja zaczyna nabierać cech swobodnej gawędy, w której na plan pierwszy wysuwa się osoba narratora, mającego przekonanie o historycznej doniosłości opisywanych zdarzeń oraz pewien dystans czasowy do przedmiotu opowieści" ${ }^{19}$. Nawet pobieżna lektura pism Sarneckiego dowiedzie jednak, że żaden z tych wymogów nie jest tam spełniony. O „swobodnej gawędzie” trudno mówić, gdy autor dąży do zachowania daleko posuniętej dyscypliny formalnej, by zadowolić Pierwszego Czytelnika,

14 J. Maternicki, Pamiętnik jako dokument kultury historycznej, „Przegląd Humanistyczny” 1985, nr 11/12, s. 231-262.

15 J. Woliński, Od wydawcy, [w:] K. Sarnecki, op. cit., s. V, VIII-X.

${ }^{16}$ Podobną praktykę zainicjuje rozpoczęta wydaniem wspomnień Jana Władysława Poczobuta Odlanickiego (1987) seria wydawnicza Pamiętniki z czasów ,, Trylogii”. Zresztą i w Antologii pamiętników polskich XVI wieku, red. R. Pollak, Wrocław-Warszawa-Kraków 1966, znajdziemy fragmenty najrozmaitszych odmian naszej szesnastowiecznej prozy pamiętnikarskiej (diariuszy, autobiografii itp.), a nie — wbrew tytułowi - tylko pamiętniki.

17 Zob. P. Borek, O polskim pamiętnikarstwie doby baroku. Rekonesans, [w:] Z dziejów staropolskiego pamiętnikarstwa. Przekroje i zbliżenia, red. P. Borek, Kraków 2012, s. 32.

18 Ibidem, s. 31-32.

19 H. Dziechcińska, Pamiętnik, s. 612. 
jeśli możemy w ten sposób określić Karola Stanisława Radziwiłła ${ }^{20}$. Sarneckiego w żadnym razie nie da się też określić „narratorem wysuwającym się na pierwszy plan", gdyż charakterystyczną cechą jego pisarstwa jest właśnie ukrywanie się za prezentowanymi wydarzeniami, a pisanie o sobie, tylko gdy jest to niezbędne ${ }^{21}$. O dystansie czasowym również trudno choćby pomyśleć, skoro mamy do czynienia z perspektywą co najwyżej jednego-dwu tygodni (a i to nie w diariuszu, lecz w liście).

Pojmując zatem pamiętnik w ujęty zwięzłą definicją sposób, nie da się wpisać w jego zakres żadnej z części dorobku stolnika witebskiego, stąd jego zastosowanie w odniesieniu do tego utworu może budzić uzasadniony sprzeciw.

Trzy lata po edycji Wolińskiego Jan Trzynadlowski opublikował propozycję podziału prozy pamiętnikarskiej, za punkt wyjścia przyjmując zagadnienia „kompozycji pamiętnika oraz stosunku form podawczych do charakteru treści przedstawionych"22. Badacz uwzględnił trzy gatunki: pamiętnik „właściwy”, diariusz oraz powieść autobiograficzną (którą finalnie usunął z perspektywy). Wspomniał też o możliwości dopuszczenia istnienia czwartego gatunku - listu lub korespondencji, zdecydował się jednak wyłączyć go ze swych rozważań. Podstawowym kryterium odróżnienia szeroko rozumianego pamiętnika od pozostałych gatunków ma być „ujawniona, epicka relacja o faktach, przytoczonych ze stanowiska własnego życia"23, wspomniane zaś odmiany wykorzystują inną metodę relacjonowania: retrospektywną (pamiętnik) oraz uteraźniejszoną (diariusz). Jak stwierdza sentencjonalnie, „w diariuszu materiał rejestrowany panuje nad rejestrującym, w pamiętniku piszący panuje nad materiałem"24. Zaproponowana systematyka, aczkolwiek spójna i bardzo klarowna, nie ułatwi nam sprawy, gdyż Sarnecki porusza się na pograniczu diariusza oraz listu, co jest podstawowym powodem trudności z ukuciem jednego terminu na określenie charakteru jego pism. Samo stwierdzenie, że mamy do czynienia z relacją uteraźniejszoną, niewystarczająco dobrze oddaje specyfikę interesującego nas dzieła. Co więcej — nawet jeśli jest to jedyny termin, który by pasował, to i tak nie objąłby obu części dorobku stolnika witebskiego (pamiętamy, że wrocławski badacz odrzucił możliwość zastosowania tego podziału przy badaniu epistolografii).

W tym samym 1961 roku ukazał się artykuł Mariana Kaczmarka, prezentujący odmienną propozycję klasyfikacji staropolskiego pamiętnikarstwa, ogra-

${ }^{20}$ Sarnecki na pewno liczył się z możliwością udostępnienia diariusza innym osobom, jednak dysponentem całości był książę podkanclerzy i to do niego należało ostatnie słowo w tej kwestii.

${ }^{21}$ I zapewne także i ten powód miał na względzie, kiedy większość osobistych uwag — których przecież i tak nie jest dużo — czynił w listach (bo te upubliczniano rzadziej niż diariusze).

22 J. Trzynadlowski, Struktura relacji pamiętnikarskiej, [w:] Księga pamiątkowa ku czci Stanistawa Pigonia, red. Z. Czerny, Kraków 1961, s. 577.

23 Ibidem.

${ }^{24}$ Ibidem, s. 579. 
niczoną jednak do XVI stulecia ${ }^{25}$. Wyróżnił (choć sam traktował to raczej jako wstęp do rozważań niż kompletny system) kronikę-pamiętnik, relację z podróży, dziennik i pamiętnik w formie listu. Trzy lata później, w niepublikowanej niestety rozprawie doktorskiej, tę listę zmodyfikował, omawiając raptularz, peregrynację, relacje poselskie, relacje-pamiętniki, kroniki mieszczańskie, diariusze $\mathrm{w}$ formie listów oraz autobiografię ${ }^{26}$. Przenosząc te ustalenia na następne stulecie, dorobek Sarneckiego mieściłby się w obrębie diariusza w formie listu, choć cały czas aktualne pozostaje zastrzeżenie, że i diariusz, i list były dla stolnika witebskiego bytami odrębnymi.

Jadwiga Rytel w poświęconej przede wszystkim Paskowi pracy odwołała się do Sarneckiego ${ }^{27}$, nie zajmowała się jednak kwestiami gatunkowymi, wskazując, że „pamiętniki Kazimierza Sarneckiego są owocem jego urzędowych obowiązków w tym charakterze [tj. magnackiego korespondenta — dop. T.Ś.] na dworze Sobieskiego" ${ }^{28}$. Mimo iż badaczka podążała za zaproponowaną przez Wolińskiego nazwą ,pamiętnik”, to jednak rozróżniła pisany regularnie diariusz oraz choć nie expressis verbis - epistolograficzny kontekst całości ${ }^{29}$.

Alojzy Sajkowski, autor najpowszechniej aprobowanej klasyfikacji form staropolskiego pamiętnikarstwa, całość dostępnego materiału podzielił na kilka grup. Wyodrębnił najpierw noty raptularzowe oraz księgi pamiętnicze, widząc w nich odrębne struktury. Resztę przypisał do pięciu głównych kategorii, z nich niektóre obejmują drobniejsze odmiany gatunkowe: relacji epistolograficznych, diariuszy, pamiętników, kronik pamiętniczych oraz pamiętników poetyckich.

Dla dorobku stolnika witebskiego, zrównanego podobieństwem przede wszystkim z relacjami Jana Piotrowskiego spod Pskowa ${ }^{30}$, poznański badacz ukuł termin „relacja epistolograficzna”, wskazując, że tego rodzaju „zespoły listów [...] stwarzają normalny dziennik sprawozdawczy"31. W regularnie prowadzonym przez Sarneckiego diariuszu widzi dodatek do podstawowej formy kontaktu z Karolem Stanisławem, czyli listownej relacji ${ }^{32}$. Trudno z takim postrzeganiem relacji między dwiema formami, z których korzystał stolnik witebski, się nie zgodzić. Istotnie to właśnie list był przeznaczony do utrzymywania kontaktu z patro-

${ }^{25}$ M. Kaczmarek, Szkice z typologii pamiętnikarstwa staropolskiego w XVI w., „Prace Polonistyczne" 1961, seria 17, s. 27-40.

26 Za: P. Borek, O polskim pamiętnikarstwie doby baroku..., s. 33.

27 J. Rytel, „Pamiętniki” Paska na tle pamiętnikarstwa staropolskiego. Szkic z dziejów prozy narracyjnej, Wrocław 1962, passim.

${ }^{28}$ Ibidem, s. 86.

29 „Piętno służbowego przeznaczenia wyryte jest w nich [tj. pamiętnikach typu relacji Sarneckiego - T.Ś.] nie tylko w początkowych i końcowych frazesach skierowanych do adresata przy przesyłaniu kolejnych partii d i a ri u s z a [wyr. — T.Ś.]", ibidem, s. 166-167.

30 J. Piotrowski, Dziennik wyprawy Stefana Batorego pod Psków, wyd. A. Czuczyński, Kraków 1894.

31 A. Sajkowski, Nad staropolskimi pamiętnikami, Poznań 1964, s. 33.

32 Ibidem, s. 44. 
nem, diariusz zaś do relacjonowania zdarzeń. Są to jednak dwie odrębne formy, z których ani diariusz nie jest inkorporowany w obręb listu, ani list do diariusza. Powstają i istnieją niemal niezależnie od siebie, choć finalnie trafiają do tego samego odbiorcy.

Zatrzymajmy się na chwilę przy Piotrowskim. Dziennik wyprawy Stefana Batorego pod Psków stał się nie tak dawno temu przedmiotem zainteresowania Marcina Bauera, który w zwięzłym studium zajął się kwestią struktury relacji w tym dziele, a w szczególności sposobem, „w jaki zastosowane przez autora konwencje listu i diariusza łączą się w nim, determinując zarazem strukturę relacji”"33. Po gruntownej analizie łódzki badacz dochodzi do wniosku, iż Dziennik, ,jest przede wszystkim diariuszem, ponieważ większość elementów widocznej w nim struktury relacji łączy go z tym właśnie gatunkiem piśmiennictwa"34. Diariusz zatem, nie list czy relacja epistolograficzna, najpełniej określa charakter tego dzieła.

Tego samego nie można jednak powiedzieć o dziele Sarneckiego. U niego granica między diariuszem a listem jest bardzo wyraźna, znacznie wyrazistsza niż u Piotrowskiego, manifestuje się — jak wskazałem w innym miejscu — odmienną strukturą oraz celami wypowiedzi. Dla stolnika witebskiego i diariusz, i list są odrębnymi bytami, pisanymi osobno i tylko pakowanymi razem. Piotrowski zaś pracował inaczej. Zdaniem Sajkowskiego „wiadomości notowane codziennie zbierało się $[\ldots] \mathrm{w}$ jedną relację, przeredagowywało, i w końcu taki fragment dziennika przesyłano w głąb kraju"35. Nie jest to zatem dzieło, które można bez wahania objąć tym samym terminem co Dziennik Piotrowskiego.

Polimorficzność staropolskiego pamiętnikarstwa jest faktem, z którego literaturoznawcy od dawna zdają sobie sprawę ${ }^{36}$. Użytkowy, a więc nieliteracki charakter tych gatunków postawił je poza obszarem zainteresowania poetyki, nie znalazły trwałej i powszechnie akceptowanej podstawy, do której przystępujący do spisywania swych wspomnień autor mógłby się odwołać i zastosować. Każdy z nich skazany był na wymyślanie takiej reguły na nowo, dla siebie. Mógł oczywiście naśladować wcześniejsze, znane sobie utwory związane z utrwalaniem pamięci o zdarzeniach, jednak nic go do tego nie przymuszało i mógł — jeśli tylko zechciał — pójść własną ścieżką.

${ }^{33}$ M. Bauer, Między listem a pamiętnikiem. O strukturze relacji w „Dzienniku wyprawy Stefana Batorego pod Psków” Jana Piotrowskiego, [w:] Z dziejów staropolskiego pamiętnikarstwa. Przekroje i zbliżenia, red. P. Borek, Kraków 2012, s. 65.

${ }^{34}$ Ibidem, s. 73. Tak samo zob. R. Lubas-Bartoszyńska, Między autobiografia a literatura, Warszawa 1993, s. 111.

35 A. Sajkowski, Nad staropolskimi pamiętnikami, s. 41. Jerzy Urwanowicz uważa, iż Piotrowski mógł się dodatkowo posiłkować pisanym przez nieznanego z imienia kolegę-sekretarza diariuszem oblężenia Pskowa (zob. Diariusz oblężenia Pskowa, wyd. J. Urwanowicz, „Zeszyt Naukowy Muzeum Wojska w Białymstoku" 1996, z. 10, s. 143-168).

${ }^{36}$ Zob. P. Borek, O polskim pamiętnikarstwie doby baroku..., s. 32. 
Tak tworzone dzieła nosiły, rzecz jasna, nadawane przez autorów tytuły. Wszystkie te diariusze, konotaty, kroniki, dzieje, peregrynacje, transakcje itp. ${ }^{37}$ lepiej lub gorzej informowały, czego się po treści może spodziewać zainteresowany czytelnik. Dziś przyjmujemy te nazwy, choć staramy się rzecz całą uporządkować i wpasować w ramy rozmaitych podziałów i systematyk. Była już o nich tutaj mowa, choć oczywiście w bardzo skróconym zarysie.

Przy jednorodności gatunkowej utworu (bo zawsze badamy konkretny tekst, nie gatunek in abstracto) sprawa jest zazwyczaj prosta i po zastosowaniu prostych narzędzi badawczych możemy ustalić, czy mamy do czynienia z diariuszem, pamiętnikiem, listem czy inną jeszcze odmianą. Rzecz cała komplikuje się jednak wtedy, gdy autor — nieistotne z jakich powodów — zdecydował się na łączenie różnych form $\mathrm{w}$ jedną, nową całość.

Taki właśnie problem związany jest z dziełem Sarneckiego. Gdybyśmy poprzestali (co uważam za najrozsądniejsze rozwiązanie) przy terminologii samego autora, czyli użylibyśmy nazw „diariusz” i ,listy”, nie musielibyśmy robić już nic więcej. Gdy jednak szukamy jednego terminu na określenie całości, niepomiernie wszystko komplikujemy. Sądzę, że nie tędy droga i że poprzestanie na utrwalonym w samym utworze nazewnictwie zupełnie wystarczy i pozwoli z należytą precyzją określić dorobek pisarski stolnika witebskiego.

\section{Bibliografia}

\section{Źródła}

Piotrowski J., Dziennik wyprawy Stefana Batorego pod Psków, wyd. A[leksander] Czuczyński, Kraków 1894.

Sarnecki K., Pamiętniki z czasów Jana Sobieskiego. Diariusz i relacje z lat 1691-1696, oprac. J. Woliński, Wrocław 1958.

\section{Opracowania}

Bauer M., Między listem a pamiętnikiem. O strukturze relacji w „Dzienniku wyprawy Stefana Batorego pod Psków” Jana Piotrowskiego, [w:] Z dziejów staropolskiego pamiętnikarstwa. Przekroje i zbliżenia, red. P. Borek, Kraków 2012, s. 65-73.

Borek P., O polskim pamiętnikarstwie doby baroku. Rekonesans, [w:] Z dziejów staropolskiego pamiętnikarstwa. Przekroje i zbliżenia, red. P. Borek, Kraków 2012, s. 32-52.

Borek P., Ukraina w staropolskich diariuszach i pamiętnikach, Kraków 2001.

Czapliński W., Długosz J., Życie codzienne magnaterii polskiej w XVII wieku, Warszawa 1976.

Dziechcińska H., Diariusz, [w:] Stownik literatury staropolskiej, red. T. Michałowska, Wrocław 1998, s. 163-165.

Dziechcińska H., Pamiętnik, [w:] Słownik literatury staropolskiej, red. T. Michałowska, Wrocław 1998, s. 610-613.

Kaczmarek M., Szkice z typologii pamiętnikarstwa staropolskiego w XVI w., „Prace Polonistyczne” 1961 , seria 17 , s. 27-40.

${ }^{37}$ H. Dziechcińska, Pamiętnik, s. 611. 
Lancholc T., List, [w:] Stownik literatury staropolskiej, red. T. Michałowska, Wrocław 1998, s. 456461.

Lubas-Bartoszyńska R., Między autobiografia a literatura, Warszawa 1993.

Maternicki J., Pamiętnik jako dokument kultury historycznej, „Przegląd Humanistyczny” 1985, nr 11/12, s. 231-262.

Rachuba A., Radziwitt Karol Stanisław, [w:] Polski stownik biograficzny, Warszawa-Kraków 1987, t. 30 .

Rytel J., „Pamiętniki” Paska na tle pamiętnikarstwa staropolskiego. Szkic z dziejów prozy narracyjnej, Wrocław 1962.

Sajkowski A., Nad staropolskimi pamiętnikami, Poznań 1964.

Sajkowski A., $W$ stronę Wiednia. Dole i niedole wojenne w świetle listów i pamiętników, Poznań 1984.

Sarnecki Kazimierz, [w:] Polski stownik biograficzny, Warszawa-Kraków 1987, t. 35, s. 208-209.

Skrzypietz A., Jakub Sobieski, Poznań 2018.

Ślęczka T., Skromny i staranny. Wybrane zagadnienia warsztatu pisarskiego Kazimierza Sarneckiego, rezydenta Karola Stanistawa Radziwiłta na dworze Jana III Sobieskiego, „Prace Literaturoznawcze" 2017, s. 61-79.

Ślęczka T., Świat zainteresowań siedemnastowiecznego magnata. Relacje Kazimierza Sarneckiego o dworze Jana III Sobieskiego, [w:] Epistolografia w dawnej Rzeczypospolitej, t. 7, red. P. Borek, M. Olma, Kraków 2017, s. 225-240.

Trzynadlowski J., Struktura relacji pamiętnikarskiej, [w:] Księga pamiątkowa ku czci Stanisława Pigonia, red. Z. Czerny, Kraków 1961, s. 577-583.

Urwanowicz J., Wstęp, [w:] Diariusz oblężenia Pskowa, „Zeszyt Naukowy Muzeum Wojska w Białymstoku" 1996, z. 10, s. 143-168.

Wójcik Z., Jan Sobieski 1629-1696, Warszawa 1983.

\title{
Diary and letters. A few remarks on the nature of Kazimierz Sarnecki's writings
}

\author{
Summary
}

The subject of the article is the issue of genre classification of the writings of Kazimierz Sarnecki, who was a permanent agent of the Deputy Chancellor of Lithuania Karol Stanisław Radziwiłł, at the court of Jan Sobieski III.

Sarnecki's main task was to obtain information about what was happening around the monarch - above all his state of health and all the other matters, even of the lowest importance.

Incarrying out his assigned tasks, Sarnecki kept a diary which, at intervals of about a week, he sent to his principal along with a separate letter. In it, he reported on his own activities, answered questions, and supplemented information that he did not record in the diary. They were two separate texts written independently but he sent them in one package. He used two different names to describe them (diary and letter).

Researchers of old Polish literature, however, were looking for a term that would allow Sarnecki's entire preserved output to be given one name.

Two such suggestions were made. The first of these comes from Janusz Woliński, the publisher of Sarnecki's work, who called it a memoir. This is not a correct term because the work does not meet any of the elements of the memoir definition (Sarnecki does not focus the narrative on himself, his storytelling of the events is subordinate to a consistent pattern, there is also no time distance to the described matters). 
The author of the second is Alojzy Sajkowski. He created the term "epistolographic relation" because in the diary he saw an element subordinate to the letter accounts; he also noticed the similarity between the writings of Sarnecki and Jan Piotrowski, who kept a diary during the siege of Pskov (1581-1582) and from time to time rephrased subsequent parts, giving them a form of a letter which he then sent to his patron, Andrzej Opaliński. This term is not correct enough either. Sarnecki was not creating one work which combined elements of a diary and a letter but two separate works a diary and a letter. Similarities with Piotrowski's diary only go so far - Sarnecki did not rephrase anything, but sent "raw" material, and did not include the diary into the letter.

That is why it is a better solution to use the names introduced by the author himself, because in this way we define the nature of his writing output most accurately.

Keywords: diary, letter, memoir, Jan III Sobieski, Kazimierz Sarnecki, Karol Stanisław Radziwiłł, Jan Piotrowski 